Article

\title{
Ecotoxicity Responses of the Macrophyte Algae Nitellopsis obtusa and Freshwater Crustacean Thamnocephalus platyurus to 12 Rare Earth Elements
}

\author{
Levonas Manusadžianas *, Rimantas Vitkus, Brigita Gylytè, Reda Cimmperman, \\ Mindaugas Džiugelis, Rolandas Karitonas and Kazys Sadauskas
}

Nature Research Centre, Institute of Botany, Žaliuju Ežeru Str. 49, 12200 Vilnius, Lithuania; vitkusr@yahoo.com (R.V.); brigita.gylyte@gamtc.lt (B.G.); reda.cimmperman@lmt.lt (R.C.); latwiso@gmail.com (M.D.); rolandas.karitonas@gamtc.lt (R.K.); sadauskas.kazys@gmail.com (K.S.)

* Correspondence: levonas.manusadzianas@gamtc.lt; Tel.: +370-684-46525

Received: 29 July 2020; Accepted: 28 August 2020; Published: 1 September 2020

\begin{abstract}
Due to unique chemical properties, rare earth elements (REEs) are increasingly used in versatile technological applications. They are considered emerging environmental contaminants, since they become mobile instead of being bound in rocks. At present, the information on REE effects to aquatic biota is scarce and contradictory. This study aims to explore the ecotoxicity of 11 lanthanides ( $\mathrm{La}, \mathrm{Ce}, \mathrm{Pr}, \mathrm{Nd}, \mathrm{Sm}, \mathrm{Eu}, \mathrm{Gd}, \mathrm{Tb}, \mathrm{Dy}, \mathrm{Er}$, and $\mathrm{Lu}$ ) and yttrium (Y) to charophyte algae Nitellopsis obtusa and microcrustaceans Thamnocephalus platyurus. Median lethal concentrations (LC50) were assessed in characean cells at $8,12,16,20$, and 24 days of exposure, and 24-h LC50s were determined in shrimps. According to the EU-Directive 93/67/EEC hazard classification scheme and 24-day LC50 values generated for N. obtusa, REE effects were assigned from "harmful" to "very toxic" (Gd), while 24-h LC50s for T. platyurus were classified as "harmful" or "toxic" (based on nominal concentrations) and as "toxic" or "very toxic" (based on REE free ion concentrations calculated with CHEAQS Next software). The data obtained for algae showed correlations with the REE atomic numbers $(\mathrm{r}=-0.68, p<0.05)$ and ionic radii $(r=0.65, p<0.05)$ at the most extended 24-day exposure only. The analysis of the trends of concentration-response (c-r) curves obtained at increasing exposure durations (8-24 days), alongside the 24-day LC50s ranging within almost two orders of magnitude, allowed a more-toxic heavy REE group to be distinguished, and somewhat different modes REE actions to be envisioned for N. obtusa.
\end{abstract}

Keywords: Nitellopsis obtusa; Thamnocephalus platyurus; toxicity; lanthanides; rare earth elements; freshwater

\section{Introduction}

A chemically homogenous group of lanthanides ( $57 \leq Z \leq 71)$, along with scandium $(Z=21)$ and yttrium $(Z=39)$, form a group of 17 species that are known as rare earth elements (REEs). Based on the structural analysis and physical and/or chemical behaviors of each element in solution, where they usually form trivalent cations, lanthanides (Lns) are divided into two subgroups: light lanthanides (LREEs) and heavy lanthanides (HREEs). The break occurring near the middle of the lanthanide series between Eu and Dy is sometimes referred to as "gadolinium break" [1,2]. The group of LREEs is characterized by a lower mean atomic mass than ca $153 \mathrm{Da}$ and a larger effective ionic radius than $95 \mathrm{pm}(\mathrm{La}, \mathrm{Ce}, \mathrm{Pr}, \mathrm{Nd}, \mathrm{Sm}$, and Eu), while the group of HREEs is distinguished by a higher mean atomic mass than ca $153 \mathrm{Da}$ and a lower effective radius than $95 \mathrm{pm}(\mathrm{Gd}, \mathrm{Tb}, \mathrm{Dy}, \mathrm{Ho}, \mathrm{Er}, \mathrm{Tm}, \mathrm{Yb}$, and $\mathrm{Lu}$, plus $\mathrm{Y}$ due to its low ion radius) [3]. The differences in ionic radii are partly responsible for dissimilarities that do exist among the elements [3]. 
Since 1980-1990 there has been an unabated demand for REE applications in diverse sectors of the world economy $[4,5]$. Because of their unique traits, REEs are indispensable in the transition to a green, low-carbon production [6], and are used in contemporary energy transforming devices, electronics and their miniaturization, medical diagnostics, and various technologies [7]. This has led to increasing quantities of e-waste [8] and, alongside with increasing fertilizer applications in agriculture [9] and untreated wastewater loads [10], to an augmented presence of REEs in environmental components. Elevated REE concentrations of anthropogenic origins have been measured, for example, in surface water (up to $0.14 \mathrm{mg} / \mathrm{kg}$ of total REEs in the effluent plume of the downstream Rhine River [11]), and sediments (up to $80 \mathrm{mg} / \mathrm{kg}$ of $\mathrm{Nd}$ in the Rhine estuary); in other words, there is as much as twice the negligible concentration level in the Netherlands, according to environmental regulations [12]. Industry- and medical-care-associated anomalous concentrations, at least of La, Sm, and Gd, have been documented in natural water bodies [11-17].

Concerning aquatic ecotoxicity, the number of studies devoted to REE toxicity for freshwater and marine biota has increased over the past several years. However, as emphasized in a review by Gonzalez et al. [5], most of the studies were conducted with La and Ce. Attention has also been paid to $\mathrm{Gd}$, due to its release into surface water through sewage systems $[15,17-19]$. Several studies on lanthanide toxicity to freshwater microalgae and crustaceans have included $\mathrm{Pr}$ and $\mathrm{Nd}$, in addition to the three Ln mentioned above $[20,21]$. Although it might be expected that Ln behavior in the environment and biological effects should be similar due to similar chemical features, there is no consensus on whether some specificity within the group does exist [5]. In this respect, simultaneous testing with a more extensive set of REEs is required to avoid variations in experimental conditions. To date, only a few studies involving more than 10 REEs are likely presented in the bibliography, one with the amphipod Hyalella azteca [22], a second with the monocellular marine alga Skeletonema costatum [23], and a third with the freshwater cnidarian Hydra attenuata [24].

Most Ln toxicity studies on aquatic flora have been carried out on freshwater microalgae, and the most frequently used species has been Pseudokirchneriella subcapitata (former Raphidocelis subcapitata) [25-29]. Other species have included Chlamidomonas reinhardtii [30-32], Desmodesmus quadricauda [33] and Chlorella [14,34]. A recent bioremediation study on rare earth removal from wastewater has incorporated several species of estuarine macroalgae [10]. As pointed out in [35], to date, many algal groups or species have not been tested for toxicity, and no tests for macroalgae have yet been developed. The lack of REE toxicity studies on freshwater macrophytic green algae inspired us to acquire data in this respect. Characeans, commonly known as stonewort, form underwater benthic plantations in oligotrophic waters, and are considered to be useful indicators of water quality [36]. The responses of internodal cells of Nitellopsis obtusa are sensitive to heavy metals and complex mixtures at the cell membrane [37], biochemical [38], and whole cell [39] levels, and have been used in various ecotoxicity studies [40-42].

In this study, we explored the ecotoxicity of 11 lanthanides (La, Ce, Pr, Nd, Sm, Eu, Gd, Tb, Dy, Er, and $\mathrm{Lu}$ ) and yttrium $(\mathrm{Y})$ to charophyte algae N. obtusa and microcrustaceans Thamnocephalus platyurus. Median lethal concentrations (LC50) assessed in characean cells at 8, 12, 16, 20, and 24 days of exposure, and 24-h LC50 values determined in shrimps were used for a comparative analysis of REE effects.

\section{Materials and Methods}

\subsection{Chemicals}

The following REE salts were used (purity > 99.9\%): cerium chloride [ $\mathrm{CeCl}_{3} \cdot 7 \mathrm{H}_{2} \mathrm{O}$ ], dysprosium chloride $\left[\mathrm{DyCl}_{3} \cdot 6 \mathrm{H}_{2} \mathrm{O}\right]$, erbium chloride $\left[\mathrm{ErCl}_{3} \cdot 6 \mathrm{H}_{2} \mathrm{O}\right]$, lanthanum chloride $\left[\mathrm{LaCl}_{3} \cdot 7 \mathrm{H}_{2} \mathrm{O}\right.$ ], neodymium chloride $\left[\mathrm{NdCl}_{3} \cdot 6 \mathrm{H}_{2} \mathrm{O}\right]$, samarium chloride $\left[\mathrm{SmCl}_{3} \cdot 6 \mathrm{H}_{2} \mathrm{O}\right]$, terbium chloride $\left[\mathrm{TbCl}_{3} \cdot 6 \mathrm{H}_{2} \mathrm{O}\right]$, and yttrium chloride $\left[\mathrm{YCl}_{3} \cdot 6 \mathrm{H}_{2} \mathrm{O}\right]$ (Sigma-Aldrich); gadolinium chloride $\left[\mathrm{GdCl}_{3} \cdot 6 \mathrm{H}_{2} \mathrm{O}\right]$, lutetium chloride $\left[\mathrm{LuCl}_{3} \cdot 6 \mathrm{H}_{2} \mathrm{O}\right]$ and praseodymium chloride $\left[\mathrm{PrCl}_{3} \cdot \mathrm{H}_{2} \mathrm{O}\right]$ (Alfa Aesar Reacton); and europium chloride $\left[\mathrm{EuCl}_{3} \cdot 6 \mathrm{H}_{2} \mathrm{O}\right.$ ] (Aeros Organics). $\mathrm{pH}$ values of $10 \mathrm{mM}$ stock solutions of each metal prepared in deionized 
water were 4.4-5.7. The chloride salts were fully soluble at this concentration of REE stocks [43]. Exposure concentrations of REE chlorides were prepared by diluting the stock solution in the corresponding control medium to reach $0.1-3000 \mu \mathrm{M}$. If required, the $\mathrm{pH}$ was adjusted to $7-8$ with $1 \mathrm{M} \mathrm{NaOH}$.

\subsection{Charophyte Algae Cell Lethality Testing}

The macrophytic alga N. obtusa (Desv.) J. Groves was harvested in Lake Obelija $\left(54^{\circ} 29^{\prime} \mathrm{N}, 23^{\circ} 83^{\prime} \mathrm{E}\right)$, southeast Lithuania [44] during vegetation (May-December) in 2018-2019. After separation from the bulk, single internodal cells were kept at room temperature $\left(20 \pm 2{ }^{\circ} \mathrm{C}\right)$ in dimly lighted glass aquariums filled with equal parts non-chlorinated tap water and medium containing $(\mathrm{mM}) 0.1 \mathrm{KH}_{2} \mathrm{PO}_{4}$, $1.0 \mathrm{NaHCO}_{3}, 0.4 \mathrm{CaCl}_{2}, 0.1 \mathrm{Mg}\left(\mathrm{NO}_{3}\right)_{2}$, and $0.1 \mathrm{MgSO}_{4}$ (unbuffered, $\mathrm{pH}$ 7.0-7.8). The chemicals were from Merck (Darmstadt, Germany).

Cell lethality testing was conducted as previously described [40]. Specifically, internodal cells (each up to $15 \mathrm{~cm}$ in length) were placed on glass Petri dishes (10-12 per dish) with artificial pond water (APW) containing (mM) $0.1 \mathrm{KCl}, 1.0 \mathrm{NaCl}, 0.5 \mathrm{CaCl}_{2}$, and $1.0 \mathrm{mM}$ HEPES (pH 7.5). The APW medium was used as a control. The cells were kept at $15-18{ }^{\circ} \mathrm{C}$ under weak illumination with LEDs at a photosynthetic photon flux density of $4-5 \mu \mathrm{mol} \mathrm{m} \mathrm{m}^{-2} \mathrm{~s}^{-1}$. Before the beginning of the testing, cells were kept for 1-2 days; this allowed dead cells that had been injured during manipulation to be discarded. A turgorless cell was judged to be dead.

Survival of the cells of N. obtusa was investigated up to 24 days. The control and working solutions were replaced on the second, fourth, and eighth day after the start of exposure. Three replicates with 10 cells per Petri dish were used for each treatment (five to eight concentrations per REE salt) and control (untreated cells). Mortality in the control did not exceed $10 \%$. Survival of the cells was checked daily until day eight, then at least every fourth day.

\subsection{Shrimp Lethality Testing}

Bioassays for the $24 \mathrm{~h}$ mortality of the T. platyurus shrimps were performed following the standard operational procedure for Thamnotoxkit F [45]. Briefly, neonates $(<24 \mathrm{~h})$ hatched from commercially available cysts were exposed to a dilution series of five to seven concentrations with three replicates per concentration. Standard freshwater medium contained (mM) $1.15 \mathrm{NaHCO}_{3}, 0.35 \mathrm{CaSO}_{4} \cdot 2 \mathrm{H}_{2} \mathrm{O}$, $0.5 \mathrm{MgSO}_{4}$, and $0.05 \mathrm{KCl}$, and was used as a control and for the diluents. Microplates with the animals were kept under controlled conditions at $25^{\circ} \mathrm{C}$ in the darkness.

\subsection{Statistical Analysis}

Two or three independent experiments with algae and five bioassays with shrimps for each REE were conducted. Median LC50 values were obtained from concentration-response (c-r) curves using Log-Logit regression [46]. To calculate the $95 \%$ confidence interval of the respective mean, toxicity results generated by each REE in distinct experiments were pooled to yield a concentration-response curve. Significant differences (at $\alpha=0.05$ ) among the LC50 values for shrimps were analyzed by one-way ANOVA followed by a Tukey's post hoc test. Prior to the ANOVA, the data set was checked to fulfil the normality (Shapiro-Wilk test) and homogeneity of variance (Levene test) requirements. For the charophyte data, statistically significant differences between the REE group means were checked by a nonparametric Mann-Whitney test. Analyses were performed with PASW Statistics 18.0 (Predictive Analytics Software, IBM).

\section{Results and Discussion}

Lethal ecotoxicity data obtained with 12 REEs are shown in Table 1 . We were not able to acquire REE 96-h LC50 estimates for N. obtusa cells contrary to those of heavy metal salts [37]. Inability to generate toxicity responses within $96 \mathrm{~h}$ of exposure signaled a lower REE toxicity to characean algae; thus, we sought the effective exposure duration. As expected, the diapason of REE LC50 values obtained for charophyte alga N. obtusa depended on the duration of exposure. For example, at an 
eight-day duration, it ranged from 32 to $286 \mathrm{mg} / \mathrm{L}$ (ninefold difference), while at a 24-day duration it ranged from 0.39 to $29.7 \mathrm{mg} / \mathrm{L}$ (76-fold difference). The toxicity data graphs from which LC50 values were derived are displayed in Figure 1. In the case of crustacean T. platyurus, 24-h LC50 values for the REE spanned 3.22 to $45.2 \mathrm{mg} / \mathrm{L}$ (14-fold difference) (i.e., varying within approx. one order of magnitude and resembling that found for algae at an eight-day exposure duration). Considering the range of effective concentrations, cnidarian H. attenuata has been shown to respond to 11 REEs within the range of $0.21-0.77 \mathrm{mg} / \mathrm{L}$ (96-h LC50s) and 0.02-0.27 mg/L (96-h EC50s, with the endpoint based on morphological changes), a 3.7- and 13.5-fold difference, respectively [24]. Tai et al. [23] explored the effect of 15 REEs on reduction in the growth of marine alga S. costatum and determined 96-h EC50 values ranging from 0.98 (scandium) to $5.01 \mathrm{mg} / \mathrm{L}$, including extremely narrow bounds for lanthanides $(4.03-5.01 \mathrm{mg} / \mathrm{L})$. Not surprisingly, ecotoxicity responses varied across species tested and the endpoints used. Taking into account the range of effective/lethal concentrations, the sensitivity row for REE-treated species outlined above is as follows: H. attenuata $(96 \mathrm{~h})>$ S. costatum $(96 \mathrm{~h})>$ T. platyurus $(24 \mathrm{~h})>N$. obtusa (8 days). These biotests with the standard exposure durations generated L(E)C50 values that differed within the respective range from approx. fourfold for Hydra to 14-fold for shrimps. It might be expected that the wider the range, the higher is the possibility of finding an REE showing a standout biological effect. For Hydra, for example, it has been found that $\mathrm{Pr}$ is a particular element in the REE group, due to an exceptionally high ratio of lethal to sublethal effects [24]; while for marine algae, neither of the lanthanides varied in their impact on algae growth [23]. In the present study, we found that T. platyurus was statistically less susceptible to $\mathrm{LaCl}_{3}$ and more reactive to $\mathrm{Y}, \mathrm{Sm}, \mathrm{Eu}$, and $\mathrm{Tb}$ chlorides (Figure 2). The extension of exposure duration from 8 to 24 days increased the sensitivity of charophyte alga cells towards REEs substantially (Table 1), approaching that of Hydra [24]. The ratio of LC50 $\max$ to $L C 50_{\min }$ values obtained for the endpoints of 8 and 24 days increased, respectively, from ninefold to 76-fold. At this most extended 24-day exposure, the heavy REE group with Gd displaying the highest toxicity to $N$. obtusa cells was generally more toxic than the light REEs. According to the ratios of 8- and 24-day LC50s (Table 1), the REE toxicity estimates split into HREE group with ratios from 15 to 143 and LREE group with ratios from 3.7 to 5.5, respectively (Table 1). The exceptions, however, are seen for Pr and Y, with ratios of 16 and 32, respectively. A comparison of the relatively long- and short-term endpoints seems to be useful when analyzing patterns of toxicity variation with time (see below). 

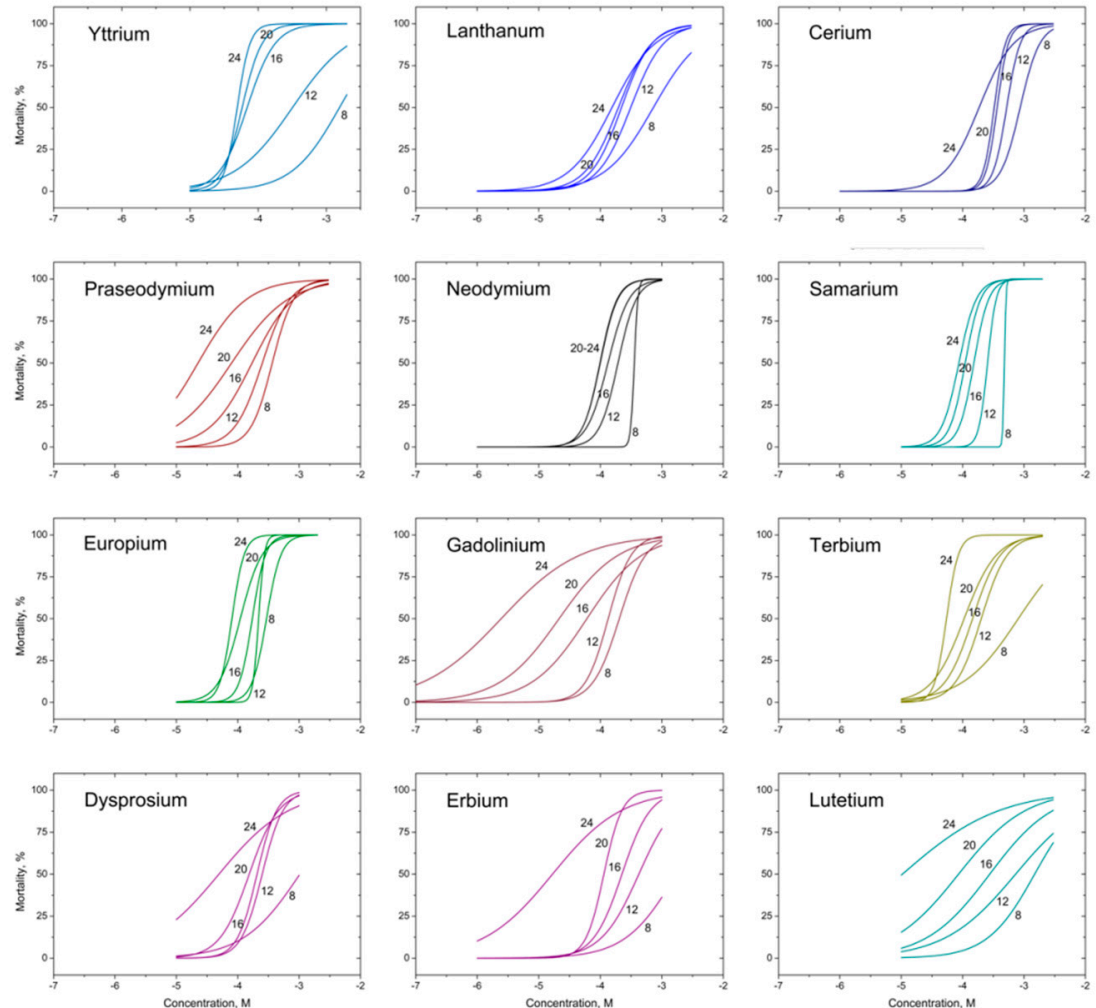

Figure 1. Concentration-response (c-r) (mortality) curves for the cells of charophyte Nitellopsis obtusa obtained at $8,12,16,20$, and 24 days of exposure in their respective rare earth element (REE) chloride salt solutions. Concentration is expressed as a logarithm of molar concentration.

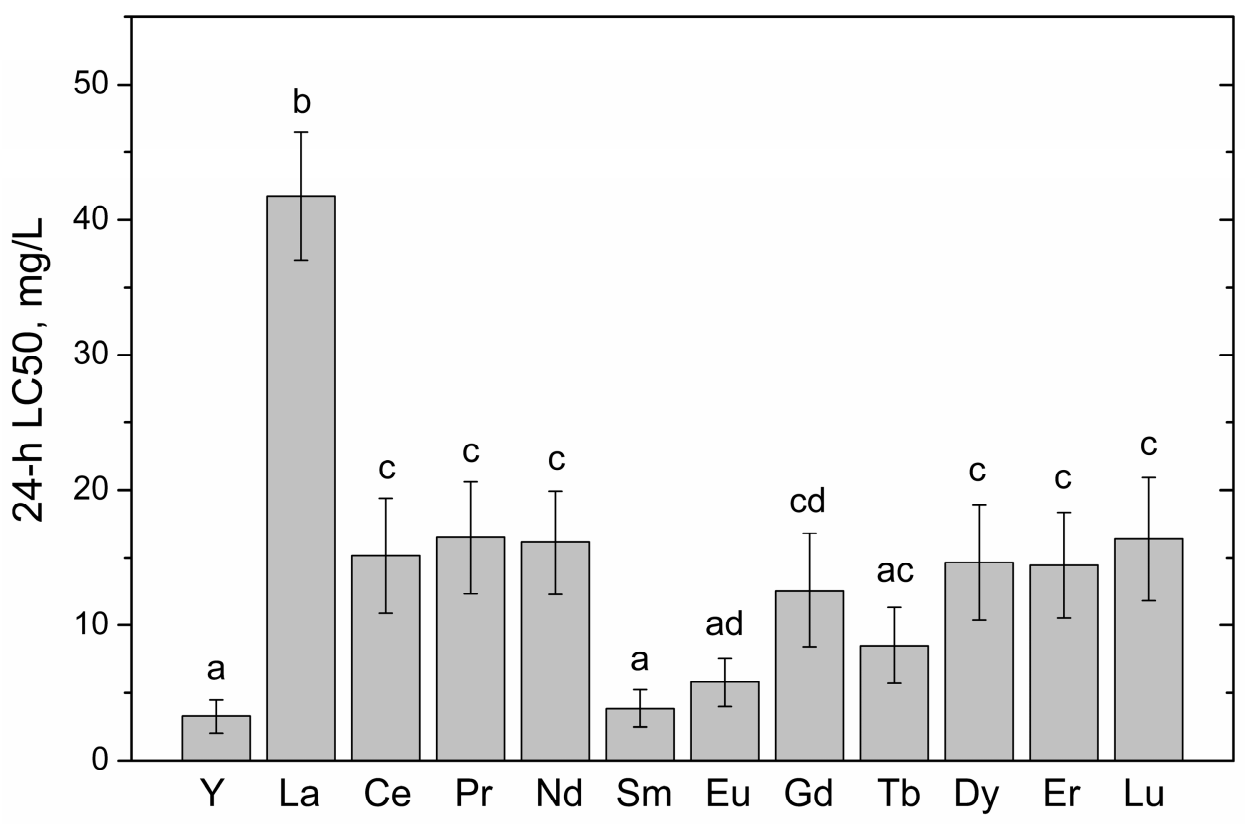

Figure 2. The 24-h LC50 values calculated from the concentration-response curves for shrimps (T. platyurus) exposed to corresponding REE chloride salt solutions (mean $\pm s d, n=5$ ). Different letters indicate a significant difference between the means $(\alpha=0.05)$. 
Table 1. The data of lethal toxicity to charophyte algae N. obtusa cells and microcrustaceans Thamnocephalus platyurus exposed to REE (III) chloride salts.

\begin{tabular}{|c|c|c|c|c|c|c|c|c|c|c|}
\hline \multirow{3}{*}{ Rare Earth Element } & \multirow{3}{*}{$\begin{array}{l}\text { Atomic } \\
\text { Number }\end{array}$} & \multirow{3}{*}{$\begin{array}{l}\text { Crystalline } \\
\text { Ionic Radius*, } \\
\text { pm }\end{array}$} & \multicolumn{6}{|c|}{ Nitellopsis obtusa } & \multirow{2}{*}{\multicolumn{2}{|c|}{$\begin{array}{c}\text { Thamnocephalus Platyurus } \\
\text { 24-h LC50 (95\% CI), mg Metal/L }\end{array}$}} \\
\hline & & & \multicolumn{5}{|c|}{ LC50 (95\% CI), mg Metal/L } & \multirow{2}{*}{$\begin{array}{c}\begin{array}{c}\text { Ratio of } \\
\text { LC50s }\end{array} \\
\begin{array}{c}8 \text { Days/24 } \\
\text { Days }\end{array}\end{array}$} & & \\
\hline & & & 8 Days & 12 Days & 16 Days & 20 Days & 24 Days & & $\begin{array}{c}\text { Based on } \\
\text { Nominal } \\
\text { Concentrations } \\
\end{array}$ & $\begin{array}{l}\text { Based on Free } \\
\text { Ion }\left[\mathbf{L n}^{3+}\right]^{* *}\end{array}$ \\
\hline Yttrium $(\mathrm{Y})$ & 39 & 106 & 138 (95.1-202) & $28.3(20.3-39.5)$ & $6.12(5.32-7.03)$ & $5.17(4.66-5.73)$ & $4.38(4.16-4.62)$ & 32 & $3.22(2.47-4.20)$ & $0.22(0.17-0.29)$ \\
\hline Lanthanum (La) & 57 & 122 & $101(77.5-132)$ & $43.3(37.1-50.5)$ & $30.7(25.2-37.3)$ & $27.3(21.6-34.6)$ & $21.5(15.7-29.5)$ & 4.7 & $45.2(39.3-51.9)$ & $10.6(9.03-12.4)$ \\
\hline Cerium (Ce) & 58 & 107 & 121 (104-141) & $73.1(65.9-80.9)$ & $51.1(46.0-56.7)$ & $45.8(14.3-50.9)$ & $26.0(19.9-33.9)$ & 4.7 & $15.1(11.6-19.8)$ & $2.23(1.68-2.97)$ \\
\hline Praseodymium (Pr) & 59 & 106 & $51.4(42.3-62.6)$ & $35.4(28.1-44.6)$ & $24.1(17.7-32.8)$ & $11.2(7.36-17.0)$ & $3.17(2.20-4.58)$ & 16 & $16.1(12.1-21.4)$ & $1.98(1.45-2.69)$ \\
\hline Neodymium $(\mathrm{Nd})$ & 60 & 104 & $51.4(47.9-55.3)$ & $28.0(23.8-32.8)$ & $19.2(16.4-22.4)$ & $14.2(12.4-16.4)$ & $14.4(11.3-18.4)$ & 3.6 & $15.2(11.2-20.5)$ & $1.52(1.10-2.09)$ \\
\hline Samarium (Sm) & 62 & 100 & $71.9(-)$ & $35.3(21.0-41.6)$ & $22.9(20.0-26.2)$ & $16.6(13.6-20.1)$ & $13.1(10.9-15.6)$ & 5.5 & $3.88(2.78-5.42)$ & $0.26(0.19-0.35)$ \\
\hline Europium $(\mathrm{Eu})$ & 63 & 98 & $44.7(37.3-53.4)$ & $33.3(31.0-35.7)$ & $26.2(22.7-30.3)$ & $16.7(13.5-20.8)$ & $12.2(9.80-15.3)$ & 3.7 & $5.20(3.87-6.98)$ & $0.35(0.25-0.47)$ \\
\hline Gadolinium (Gd) & 64 & 97 & $32.0(25.5-40.2)$ & $22.2(18.7-26.4)$ & $17.1(13.8-21.1)$ & $3.30(2.33-4.68)$ & $0.39(0.23-0.66)$ & 83 & $11.8(7.96-17.5)$ & $0.90(0.59-1.37)$ \\
\hline Terbium (Tb) & 65 & 93 & $128(81.6-201)$ & $31.9(25.8-39.6)$ & $23.1(18.3-29.1)$ & $16.8(12.9-21.9)$ & $8.67(7.02-10.7)$ & 15 & $8.11(5.60-11.8)$ & $0.51(0.34-0.77)$ \\
\hline Dysprosium (Dy) & 66 & 91 & $167(82.2-339)$ & $40.6(31.8-52.0)$ & $33.5(26.3-42.6)$ & $25.0(17.8-35.1)$ & $8.01(3.29-19.5)$ & 21 & $15.7(12.6-19.5)$ & $0.84(0.66-1.08)$ \\
\hline Erbium (Er) & 68 & 89 & $286(117-700)$ & $70.7(55.3-90.3)$ & $37.6(30.3-46.6)$ & $19.1(15.9-23.1)$ & $2.79(1.47-5.29)$ & 103 & $14.6(11.7-18.4)$ & $0.66(0.52-0.85)$ \\
\hline Lutetium (Lu) & 71 & 85 & $260(165-412)$ & 127 (83.1-195) & $48.2(34.9-66.7)$ & $15.0(8.40-26.7)$ & $1.82(0.59-5.63)$ & 143 & $15.7(12.2-20.3)$ & $0.51(0.38-0.69)$ \\
\hline
\end{tabular}

${ }^{*}$ Emsley [47]. ** LC50 values calculated with the software CHEAQS Next [48]. 
Hazard potential of the REEs to characean algae and shrimps can be estimated according to the EU Directive 93/67/EEC classification scheme [49], wherein toxicity responses are classified into five categories (i.e., "non-toxic (effects > $100 \mathrm{mg} / \mathrm{L}$ )", "harmful (effects between 10 and $100 \mathrm{mg} / \mathrm{L}$ )", "toxic (effects between 1 and $10 \mathrm{mg} / \mathrm{L}$ )", "very toxic (effects between 0.1 and $1 \mathrm{mg} / \mathrm{L}$ )", and "extremely toxic (effects $<0.1 \mathrm{mg} / \mathrm{L}$ ). The REE effects observed for T. platyurus in this study can thus be classified as "harmful" (La, Ce, Pr, Nd, Gd, Tb, Dy, Er, and Lu) or "toxic" (Y, Sm, and Eu) (Table 1). The similar toxicity categorization of the five lanthanides (i.e., $\mathrm{La}, \mathrm{Ce}, \mathrm{Pr}, \mathrm{Nd}$, and $\mathrm{Gd}$ ) could also be assigned to the findings of Blinova et al. [21] on T. platyurus treated under identical testing conditions. However, the authors have mentioned that nominal concentrations should not be used for calculating toxicity endpoints in acute tests, as higher concentrations are usually used in short-term tests to see an effect. The REEs tend to form complexes in water containing organic and/or inorganic ligands. They can be bound by substances presenting in natural organic matter and form insoluble or poorly soluble complexes in test media with anions like phosphate and carbonate [50-52]. This is especially true when artificial media are nutritious (e.g., microalgae growth medium). The authors in [21] evaluated 24-h LC50 values for T. platyurus based on measured concentrations of five Lns at the end of exposure and found them to range from 0.2 to $1.5 \mathrm{mg} / \mathrm{L}$. To evaluate REE speciation in our study, we recalculated LC50s based on free ion concentrations of each REE at nominal exposure concentrations and medium constituent concentrations using CHEAQS Next software [48]. The estimates are presented in the last column of Table 1. Accordingly, seven lanthanides ( $\mathrm{Sm}-\mathrm{Lu}$ ) and $\mathrm{Y}$ could now be classified as "very toxic" with LC50s $0.2-0.9 \mathrm{mg} / \mathrm{L}$, while three of them (i.e., Ce, Pr, and Nd) could be classified as "toxic" with LC50s 1.5-2.2 mg/L. Comparison of the two sets of EC50s obtained with nominal and free ion $\left(\mathrm{Ln}^{3+}\right)$ concentrations showed a speciation effect that is stronger at the heavier end of REEs (ratios of LC50 values equaling 20-30 for Dy, Er, and Lu, and 4-10 for La, Ce, Pr, and Nd). Although qualitatively the toxicity patterns within the two LC50 sets remained generally similar, with Y, Sm, and Eu being the most and La the least toxic REEs to T. platyurus, the relationships between nominal and "neat" active concentrations seem to be complex, in particular when REEs are considered as a group.

Regarding REE 24-day LC50 values generated for N. obtusa, rare earth metal effects were assigned to "harmful" (La, Ce, Nd, Sm, and Eu), "toxic" (Y, Pr, Tb, Dy, Er, and Lu) and "very toxic" (Gd) (Table 1). For comparison, an earlier study conducted on heavy metal salts with the same charophyte algae species estimated 96-h LC50 values that spanned over three orders of magnitude (i.e., from $<1 \mathrm{mg} / \mathrm{L}$ $(\mathrm{Cu}, \mathrm{Hg}$, and $\mathrm{Cd})$ to $>100 \mathrm{mg} / \mathrm{L}(\mathrm{Cr}))$ [37]. Considering hazard potentials [48], rare earth metal salts tested were less toxic to the macrophytic algae of $N$. obtusa than those of heavy metals, especially if the test durations at which the data were generated are considered. It should be mentioned that, contrary to the test medium for invertebrates containing carbonate and sulphate, the medium used in charophyte algae survival observations contained only chloride salts, and thus speciation effects in the water bulk were not expected. Some changes of exposure concentrations could occur due to adsorption of REEs onto glass Petri dishes, as was documented for La (up to $25 \%$ of the total amount [53]). In our experiments, this possibility was diminished, since media were periodically renewed.

The trends of concentration-response curves obtained for N. obtusa internodal cells that were exposed to the REEs for varying durations (from 8 to 24 days) are displayed in Figure 1. From the visual inspection, two groups of the families of the curves' dynamics can be seen. For the first one, an increase in exposure duration did not lead to elevated cell mortality rates at concentrations equal to approx. $10^{-5} \mathrm{M}$, i.e., for $\mathrm{Y}, \mathrm{La}, \mathrm{Ce}, \mathrm{Nd}, \mathrm{Sm}, \mathrm{Eu}$, and $\mathrm{Tb}$ (the mean of the 24 -day LC50s was $14.3 \mathrm{mg} / \mathrm{L}$ ). For the second one, an increase in exposure duration led to elevated cell mortality rates at concentrations of $10^{-5} \mathrm{M}$ and below, i.e., for $\mathrm{Gd}, \mathrm{Dy}, \mathrm{Er}, \mathrm{Lu}$, and $\operatorname{Pr}$ (the mean of the 24-day LC50s as $3.2 \mathrm{mg} / \mathrm{L}$ ). The means differed significantly (Mann-Whitney test, $p=0.01$ ). The above-mentioned classification shows a similar result to the traditional division according to atomic numbers. Specifically, the major part of the LREEs (except Pr) belonged to the first, while that of HREEs (except $\mathrm{Tb}$ ) belonged to the second group. The means of the 24-day LC50 values of light REEs (Y, La, Ce, Pr, Nd, Sm, and Eu) and heavy REEs (Gd, $\mathrm{Tb}, \mathrm{Dy}, \mathrm{Er}$, and $\mathrm{Lu}$ ) were 8.4 and $3.8 \mathrm{mg} / \mathrm{L}$, respectively, and were statistically significantly different 
(Mann-Whitney test, $p=0.03$ ). Therefore, the HREEs were generally more toxic to charophyte cells than the LREEs.

An analysis of the shape changes of concentration-response (c-r) curves obtained at various exposures suggests that REEs are not a uniform group of chemicals, and likely have different modes of action for charophyte algae cells. For example, within the less toxic REE group, c-r curves of $\mathrm{Ce}, \mathrm{Nd}$, and $\mathrm{Sm}$ became less steep when the duration increased due to a more significant alteration of the lower part of the curves. In contrast, the $\mathrm{c}-\mathrm{r}$ curves of $\mathrm{Y}, \mathrm{La}$, and $\mathrm{Tb}$ became steeper (Figure 1). Within the more toxic REE group, the $\mathrm{c}-\mathrm{r}$ curves of $\mathrm{Gd}, \mathrm{Pr}$, and Lu became less steep when the duration increased due to the same reason as mentioned above, while the $\mathrm{c}-\mathrm{r}$ curves of $\mathrm{Y}, \mathrm{La}$, and $\mathrm{Tb}$ became steeper (Figure 1).

Lanthanide concentrations in the surface water in the Netherlands have been reported to be up to $0.12 \mathrm{mg} / \mathrm{L}$ [54]. The values of 24-day LC20 for Gd, Er, Dy, or Pr obtained in our study ranged from 0.05 to $1.5 \mathrm{mg} / \mathrm{L}$ (Figure 1) and it is most likely that an extension of the exposure duration at these LC20 effect concentrations would eventually result in 100\% mortality. Considering the hazard potential, it might thus be expected that REEs exhibiting the second type of $\mathrm{c}-\mathrm{r}$ curve dynamics are more hazardous to characeans.

The 24-day LC50s displayed an increasing trend in toxicity as lanthanide atomic numbers increased $(r=-0.68, p<0.05$, Figure $3 \mathrm{~A})$; however, to yield the relationship, it was necessary to exclude $Y$ from the data set. No statistically significant correlations were found between atomic numbers and either of the 8-, 12-, 16-, or 20-day LC50 values for algae, as well as between atomic numbers and 24-h LC50 values for shrimps. As with REE atomic numbers, the ionic radii were only correlated significantly with 24-day LC50s for N. obtusa, including yttrium ( $r=0.65, p<0.05$, Figure 3B). Although both correlations explain about $40 \%$ of the variation, it seems that either of these REE atomic characteristics possesses some influence over toxicity to the cells of $N$. obtusa. In this respect, other studies have reported inverse correlations of the atomic number with the toxicities to Hydra attenuata [24] and the freshwater invertebrate Hyalella azteca [22], which were opposite to that found in our study; however, to get the relationships, the heaviest lanthanides had to be omitted.
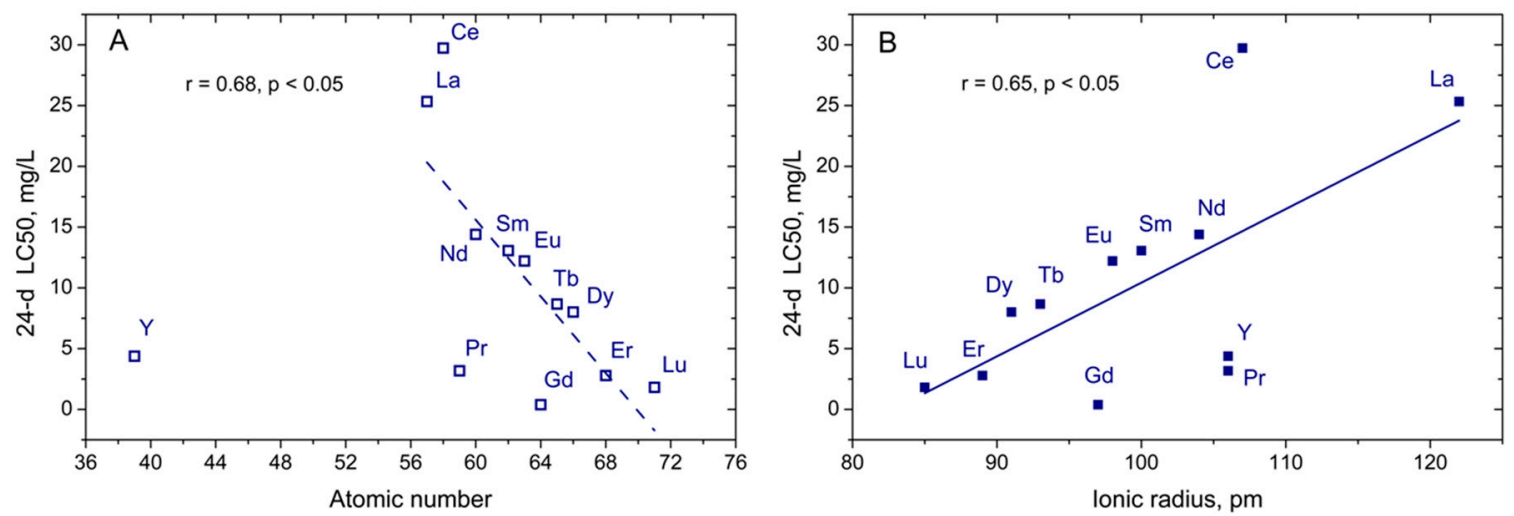

Figure 3. The correlation between 24-day LC50 values obtained for algae N. obtusa exposed to REEs and atomic number (A) or ionic radius (B). Yttrium (Y) was not included in the linear regression analysis (A, dotted line).

\section{Conclusions}

This study demonstrated that toxicity of 12 REEs to both tested species, macroalgae Nitellopsis obtusa and microcrustaceans Thamnocephalus platyurus, varied noticeably. Although 24-h exposure for shrimps was sufficient to reveal their varying sensitivity to several REEs, longer exposures were required in the case of charophyte algae. The heavier REEs were significantly more toxic to algae than the lighter ones. The HREEs also demonstrated substantial mortalities within 24 days at $10 \mu \mathrm{M}$ or 
lower concentrations that were close to those found in surface waters [48]. Overall, the REEs proved to be less toxic to N. obtusa than heavy metals [37].

The lethal effect data obtained for N. obtusa internodal cells showed correlations with the REE atomic numbers and ionic radii at the most extended 24-day exposure only. The relationships suggest a possible linkage of the chemical/physical properties of REEs and their biological effects. The span of 24-day LC50 values within almost two concentration orders, alongside the different trends of concentration-response curves obtained at increasing exposure durations, allowed dissimilar modes of action to be envisioned for REEs. The effect specificity might be related to characean cell wall properties, where the elements can be specifically bound and thereby appear intracellularly with some delay; however, to confirm this, further studies are needed.

Author Contributions: Conceptualization, L.M., R.V., and K.S.; methodology, B.G., R.C., and M.D.; formal analysis, K.S., R.C., and B.G.; investigation, M.D., R.K., B.G., and R.C.; data curation, R.V., B.G., and R.K.; writing-original draft preparation, B.G. and L.M.; writing-review and editing, L.M., and R.V.; supervision, L.M. All authors have read and agreed to the published version of the manuscript.

Funding: This research was supported by the Nature Research Centre R\&D III program.

Acknowledgments: We would like to thank Mme V. Ptašekienè for linguistic assistance.

Conflicts of Interest: The authors declare no conflict of interest.

\section{References}

1. Rigault, S.; Piguet, C. Predictions and assignments of NMR spectra for strongly paramagnetic supramolecular lanthanide complexes: The effect of the "gadolinium break". J. Am. Chem. Soc. 2000, 122, 9304-9305. [CrossRef]

2. Arnold, D.P.; Jiang, J. Distinction between light and heavy lanthanide(III) ions based on the ${ }^{1} \mathrm{H}$ NMR spectra of heteroleptic triple-decker phthalocyaninato sandwich complexes. J. Phys. Chem. 2001, 105, 7525-7533. [CrossRef]

3. Tyler, G. Rare earth elements in soil and plant systems-A review. Plant Soil 2004, 267, 191-206. [CrossRef]

4. Alonso, E.; Sherman, A.M.; Wallington, T.J.; Everson, M.P.; Field, F.R.; Roth, R.; Kirchain, R.E. Evaluating rare earth element availability: A case with revolutionary demand from clean technologies. Environ. Sci. Technol. 2012, 46, 3406-3414. [CrossRef]

5. Gonzalez, V.; Vignati, D.A.L.; Leyval, C.; Giamberini, L. Environmental fate and ecotoxicity of lanthanides: Are they a uniform group beyond chemistry? Environ. Int. 2014, 71, 148-157. [CrossRef]

6. Binnemans, K.; Jones, P.T.; Blanpain, B.; Van Gerven, T.; Yang, Y.; Walton, A.; Buchert, M. Recycling of rare earths: A critical review. J. Clean. Prod. 2013, 51, 1-22. [CrossRef]

7. Balaram, V. Rare Earth Elements: A review of applications, occurrence, exploration, analysis, recycling, and environmental impact. Geosci. Front. 2019, 10, 1285-1303. [CrossRef]

8. Tansel, B. From electronic consumer products to e-wastes: Global outlook, waste quantities, recycling challenges. Environ. Int. 2016, 98, 35-45. [CrossRef]

9. Gwenzi, W.; Mangori, L.; Danha, C.; Chaukura, N.; Dunjana, N.; Sanganyado, E. Sources, behaviour, and environmental and human health risks of high-technology rare earth elements as emerging contaminants. Sci. Total Environ. 2018, 636, 299-313. [CrossRef]

10. Costa, M.; Henriques, B.; Pinto, J.; Fabre, E.; Dias, M.; Soares, J.; Carvalho, L.; Vale, C.; Pinheiro-Torres, J.; Pereira, E. Influence of toxic elements on the simultaneous uptake of rare earth elements from contaminated waters by estuarine macroalgae. Chemosphere 2020, 252, 126562. [CrossRef]

11. Kulaksiz, S.; Bau, M. Anthropogenic dissolved and colloid/nanoparticle-bound samarium, lanthanum and gadolinium in the Rhine River and the impending destruction of the natural rare earth element distribution in rivers. Earth Planet. Sci. Lett. 2013, 362, 43-50. [CrossRef]

12. Sneller, F.E.C.; Kalf, D.F.; Weltje, L.; Van Wezel, A.P. Maximum Permissible Concentrations and Negligible Concentrations for Rare Earth Elements (REE); RIVM Report No. 601501011; National Institute of Public Health and the Environment: Bilthoven, The Netherlands, 2000.

13. Kulaksiz, S.; Bau, M. Rare earth elements in the Rhine River, Germany: First case of anthropogenic lanthanum as a dissolved microcontaminant in the hydrosphere. Environ. Int. 2011, 37, 973-979. [CrossRef] 
14. Romero-Freire, A.; Minguez, L.; Pelletier, M.; Cayer, A.; Caillet, C.; Devin, S.; Gross, E.M.; Guérold, F.; Pain-Devin, S.; Vignati, D.A.L.; et al. Assessment of baseline ecotoxicity of sediments from a prospective mining area enriched in light rare earth elements. Sci. Total Environ. 2018, 612, 831-839. [CrossRef]

15. Möller, P.; Paces, T.; Dulski, P.; Moteani, G. Anthropogenic Gd in surface water, drainage system, and the water supply of the city of Prague, Czech Republic. Environ. Sci. Technol. 2002, 36, 2387-2394. [CrossRef]

16. Rogowska, J.; Olkowska, E.; Ratajczyk, W.; Wolska, L. Gadolinium as a new emerging contaminant of aquatic environment. Environ. Toxicol. Chem. 2018, 37, 1523-1534. [CrossRef]

17. Brünjes, R.; Hofmann, T. Anthropogenic gadolinium in freshwater and drinking water systems. Water Res. 2020, 182, 115966. [CrossRef]

18. Atinkpahoun, C.N.H.; Pons, M.-N.; Louis, P.; Leclerc, J.-P.; Henri, H.; Soclo, H.H. Rare earth elements (REE) in the urban wastewater of Cotonou (Benin, West Africa). Chemosphere 2020, 251, 126398. [CrossRef]

19. Bau, M.; Knappe, A.; Dulski, P. Anthropogenic gadolinium as a micropollutant in river waters in Pennsylvania, and in Lake Erie, northeastern United States. Chem. Erde 2006, 66, 143-152. [CrossRef]

20. Kurvet, I.; Juganson, K.; Vija, H.; Sihtmäe, M.; Blinova, I.; Syvertsen-Wiig, G.; Kahru, A. Toxicity of nine (doped) rare earth metal oxides and respective individual metals to aquatic microorganisms Vibrio fischeri and Tetrahymena thermophila. Materials 2017, 10, 754. [CrossRef]

21. Blinova, I.; Lukjanova, A.; Muna, M.; Vija, H.; Kahru, A. Evaluation of the potential hazard of lanthanides to freshwater microcrustaceans. Sci. Total Environ. 2018, 642, 1100-1107. [CrossRef]

22. Borgmann, U.; Couillard, Y.; Doyle, P.; Dixon, G. Toxicity of sixty-three metals and metalloids to Hyalella azteca at two levels of water hardness. Environ. Toxicol. Chem. 2005, 24, 641-652. [CrossRef]

23. Tai, P.; Zhao, Q.; Su, D.; Li, P.; Stagnitti, F. Biological toxicity of lanthanide elements on algae. Chemosphere 2010, 80, 1031-1035. [CrossRef]

24. Blaise, C.; Gagné, F.; Harwood, M.; Quinn, B.; Hanana, H. Ecotoxicity responses of the freshwater cnidarian Hydra attenuata to 11 rare earth elements. Ecotoxicol. Environ. Saf. 2018, 163, 486-491. [CrossRef]

25. Mannier, N.; Bado-Nilles, A.; Delalain, P.; Aguerre-Chariol, O.; Pandard, P. Ecotoxicity of non-aged and aged $\mathrm{CeO}_{2}$ nanomaterials towards freshwater microalgae. Environ. Pollut. 2013, 180, 63-70. [CrossRef]

26. Gonzalez, V.; Vignati, D.A.L.; Pons, M.-N.; Montarges-Pelletier, E.; Bojic, C.; Giamberini, L. Lanthanide ecotoxicity: First attempt to measure environmental risk for aquatic organism. Environ. Pollut. 2015, 199, 139-147. [CrossRef]

27. Joonas, E.; Aruoja, V.; Olli, K.; Syvertsen-Wiig, G.; Vija, H.; Kahru, A. Potency of (doped) rare earth oxide particles and their constituent metals to inhibit algal growth and induce direct toxic effects. Sci. Total Environ. 2017, 593-594, 478-486. [CrossRef]

28. Romero-Freire, J.E.; Muna, M.; Cossu-Leguille, C.; Vignati, D.A.L.; Giamberini, L. Assessment of the toxic effects of mixtures of three lanthanides (Ce, Gd, Lu) to aquatic biota. Sci. Total Environ. 2019, 661, 276-284. [CrossRef]

29. Bergsten-Torralba, L.R.; Magalhães, D.P.; Giese, E.C.; Nascimento, C.R.S.; Pinho, J.V.A.; Buss, D.F. Toxicity of three rare earth elements, and their combinations to algae, microcrustaceans, and fungi. Ecotoxicol. Environ. Saf. 2020, 201, 110795. [CrossRef]

30. Röhder, L.A.; Brandta, T.; Sigg, L.; Behra, R. Influence of agglomeration of cerium oxide nanoparticles and speciation of cerium(III) on short term effects to the green algae Chlamydomonas reinhardtii. Aquat. Toxicol. 2014, 152, 121-130. [CrossRef]

31. El-Akl, P.; Smith, S.; Wilkinson, K.J. Linking the chemical speciation of cerium to its bioavailability in water for a freshwater alga. Environ. Chem. Toxicol. 2015, 34, 1711-1719. [CrossRef]

32. Tan, Q.-G.; Yang, G.; Wilkinson, K.J. Biotic ligand model explains the effects of competition but not complexation for Sm biouptake by Chlamydomonas reinhardtii. Chemosphere 2017, 168, 426-434. [CrossRef] [PubMed]

33. Ǩezanka, T.; Kaineder, K.; Mezricky, D.; Řezanka, M.; Bišová, K.; Zachleder, V.; Vítová, M. The effect of lanthanides on photosynthesis, growth, and chlorophyll profile of the green alga Desmodesmus quadricauda. Photosynth. Res. 2016, 130, 335-346. [CrossRef] [PubMed]

34. Fujiwara, K.; Matsumoto, Y.; Kawakami, H.; Aoki, M.; Tuzuki, M. Evaluation of metal toxicity in Chlorella kessleri from the perspective of the periodic table. Bull. Chem. Soc. Jpn. 2008, 81, 478-488. [CrossRef]

35. Vítová, M.; Č́žková, M.; Zachleder, V. Lanthanides and Algae. In Lanthanides; Awwad, N.S., Mubarak, A.T., Eds.; IntechOpen: London, UK, 2018. [CrossRef] 
36. van den Berg, M.S.; Scheffer, M.; Coops, H.; Simons, J. The role of characean algae in the management of eutrophic shallow lakes. J. Phycol. 1998, 34, 750-756. [CrossRef]

37. Manusadžianas, L.; Maksimov, G.; Darginavičienè, J.; Jurkonienè, S.; Sadauskas, K.; Vitkus, R. Response of charophyte Nitellopsis obtusa to heavy metals at the cellular, cell membrane and enzyme levels. Environ. Toxicol. 2002, 17, 275-283. [CrossRef]

38. Grigutytè, R.; Nimptsch, J.; Manusadžianas, L.; Pflugmacher, S. Response of oxidative stress enzymes in charophyte Nitellopsis obtusa exposed to allochthonous leaf extracts from beech Fagus sylvatica. Biologija 2009, 55, 142-149. [CrossRef]

39. Gylytè, B.; Manusadžianas, L.; Sadauskas, K.; Vitkus, R.; Jurkonienè, S.; Karitonas, R.; Petrošius, R.; Skridlaitè, G.; Vaičiūnienè, J. Latent cell mortality after short-term exposure of Nitellopsis obtusa cells to copper oxide nanoparticles. Botanica 2015, 21, 89-98. [CrossRef]

40. Manusadžianas, L.; Caillet, C.; Fachetti, L.; Gylytė, B.; Grigutytè, R.; Jurkonienè, S.; Karitonas, R.; Sadauskas, K.; Thomas, F.; Vitkus, R.; et al. Toxicity of copper oxide nanoparticle suspensions to aquatic biota. Environ. Toxicol. Chem. 2012, 31, 108-114. [CrossRef]

41. Manusadžianas, L.; Gylytė, B.; Grigutytè, R.; Karitonas, R.; Sadauskas, K.; Vitkus, R.; Šiliauskas, L.; Vaičiūnienè, J. Accumulation of copper in the cell compartments of charophyte Nitellopsis obtusa after its exposure to copper oxide nanoparticle suspension. Environ. Sci. Pollut. Res. 2017, 24, 27653-27661. [CrossRef]

42. Jurkonienė, S.; Maksimov, G.; Darginavičienė, J.; Sadauskas, K.; Vitkus, R.; Manusadžianas, L. Leachate toxicity assessment by responses of algae Nitellopsis obtusa membrane ATPase and cell resting potential, and with Daphtoxkit FTM magna test. Environ. Toxicol. 2004, 19, 403-408. [CrossRef]

43. Gumińsky, C. Solubility and the periodic table of elements. Pure Appl. Chem. 2015, 87, 477-485. [CrossRef]

44. Kostkevičienè, J.; Sinkevičienè, Z. A preliminary checklist of Lithuanian macroalgae. Bot. Lith. 2008, 14, 11-27.

45. SOP (Standard Operating Procedure). Thamnotoxkit $\mathrm{F}^{\mathrm{TM}}$. In Crustacean Toxicity Screening Test for Freshwater; Microbiotests: Gent, Belgium, 2014.

46. Environment Canada. Guidance Document on Statistical Methods for Environmental Toxicity Tests; Report EPS 1/RM/46; Environment Canada: Ottawa, ON, Canada, 2005.

47. Emsley, J. The Elements; Clarendon Press: Oxford, UK, 1991.

48. Verweij, W. CHEAQS: A Program for Calculating Chemical Equilibria in Aquatic Systems (CHEAQS Pro, succeeded by CHEAQS Next), version 2020.2, dated July 2020. Available online: https://www.cheaqs.eu (accessed on 17 August 2020).

49. CEC (Commission of the European Communities). Technical Guidance Document in Support of Commission Directive 93/67/EEC on Risk Assessment for New Notified Substances. Part. II, Environmental Risk Assessment; Office for Official Publications of the European Communities: Luxembourg, 1996.

50. Barry, M.; Meehan, B.J. The acute and chronic toxicity of lanthanum to Daphnia carinata. Chemosphere 2000, 41, 1669-1674. [CrossRef]

51. Weltje, L.; Verhoof, L.R.C.W.; Verweij, W.; Hamers, T. Lutetium speciation and toxicity in microbial bioassay: Testing the free-ion model for lanthanides. Environ. Sci. Technol. 2004, 38, 6597-6604. [CrossRef]

52. Ma, Y.; Wang, J.; Peng, C.; Ding, Y.; He, X.; Zhang, P.; Li, N.; Lan, T.; Wang, D.; Zhang, Z.; et al. Toxicity of cerium and thorium on Daphnia magna. Ecotoxicol. Environ. Saf. 2016, 134, 226-232. [CrossRef]

53. Weltje, L.; Brouwer, A.H.; Verburg, T.G.; Wolterbeek, H.T.; de Goeij, J.J.M. Accumulation and elimination of lanthanum by duckweed (Lemna minor L.) as influenced by organism growth and lanthanum sorption to glass. Environ. Toxicol. Chem. 2002, 21, 1483-1489. [CrossRef]

54. Weltje, L.; Heidenreich, H.; Zhu, W.; Wolterbeek, H.T.; Korhammer, S.; de Goeij, J.J.M.; Markert, B. Lanthanide concentrations in freshwater plants and molluscs, related to those in surface water, pore water and sediment. A case study in The Netherlands. Sci. Total Environ. 2002, 286, 191-214. [CrossRef]

(C) 2020 by the authors. Licensee MDPI, Basel, Switzerland. This article is an open access article distributed under the terms and conditions of the Creative Commons Attribution (CC BY) license (http://creativecommons.org/licenses/by/4.0/). 